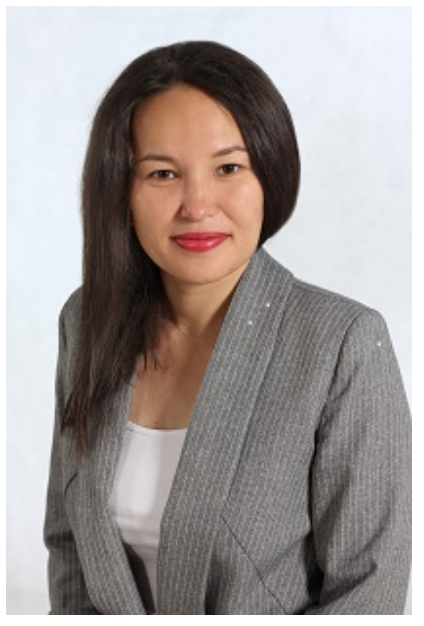

DOI 10.31554/978-5-7925-0571-1-2019-2-184-188
Elena Evgenyevna Tinikova, Candidate of History, Senior Researcher of the Department for International and Interregional Relations of the Khakass research Institute of language, literature and history Abakan, Russia lena.tinikova@mail.ru

\title{
URBANIZATION AND ITS IMPACT ON THE LIFESTYLE OF RESIDENTS OF KHAKASSIA IN THE MIDDLE OF THE XX - EARLY XXI CENTURIES *
}

The analysis of the modification of the lifestyle of the population in the Republic of Khakassia in the conditions of intensive stage of urbanization is carried out on the basis of a sociological study conducted in the summer of 2018, as well as on the basis of official statistics. Indicators that allow us to characterize the way of life of people were: the level and structure of employment, the distribution of free time, housing and living conditions.

Taking into account the fact that today it is already quite difficult to draw a clear border between the city and the village, since the "rural" environment is no longer typically rural, not only residents of cities but also villages of the region participated in the sociological survey. Also, the study took into account the ethnic factor, which, of course, has an impact on the urbanization processes in the republic. For example, the Khakas were much later included in the studied processes than the East Slavic peoples. The way of life of urban Khakas contrasted more with the way of life of rural Khakas, the latter found it more difficult to adapt to the urban environment.

* The work was carried out with the financial support of the RFBR, project No. 18-39-00074 (_a) "Study of the regional model of urban development of southern Siberia in 1945-2017”. 
The preserved traditions, the language barrier and external anthropological features of the Khakas played an important role. Therefore, respondents of the sociological survey were initially divided into 2 large ethnic groups: Khakas and Russians. In general, the empirical study surveyed 500 urban Khakas and 500 Russians, as well as 500 rural Khakas. The sample included all socio-demographic groups of adults over 18 years.

Keywords: urbanization, lifestyle, Khakassia, city, village.

In modern conditions urbanization plays an increasingly important role in the development of Russian society and determines the vectors of transformation of the main spheres of its life. Urbanization is always accompanied by a change in lifestyle of people living not only in urban areas, but also in rural areas. The concept of "lifestyle" is interpreted in science ambiguously. This is due to the existence of different methodological approaches and largely depends on the objectives of specific studies. In this article the "lifestyle" is understood as a set of characteristics such as the possibility of organizing labor, household and leisure of a person [Zarukina 2017, p. 137]. In this regard, the analysis of the modification of the lifestyle of residents of Khakassia in the conditions of intensive stage of urbanization is carried out on the basis of the characteristics of the following indicators: employment, distribution of free time, housing and living conditions.

A person's lifestyle is largely determined by the nature of his work. Back in the middle of the twentieth century in order to overcome the differences between the city and the countryside the Soviet state decided to consider rural labor as a kind of industrial [Sidorova 2019, p. 29]. As a result, collective farmers and members of their families began to represent the agrarian detachment of the working class, thereby increasing its number. Nevertheless, it is necessary to clearly separate the working class of cities, working villages and people working in state farms. In general, official statistics show that workers and employees made up the absolute majority of citizens, determining the social appearance of urban settlements. The share of workers and employees in the entire population of urban settlements of Khakassia in 1989 reached $99.3 \%$, including workers - $69 \%$, employees - $30.3 \%$, among the employed population respectively - $99.8 \%$; $68.3 \%$; $31.5 \%$ [Collection..., p. 5-6].

After the collapse of the Soviet Union in the conditions of socioeconomic crisis rural migrants rushed in the urban settlements of Khakassia, whose main goal was to find work. The situation as a whole has not changed 
today: respondents who took part in our sociological study and migrated to urban settlements set goals related to employment. This is the lack of work in the village and the desire to find work in the city (24.6\% of respondents), the desire to live better, earn more (24.1\%). It should be noted that there is a slight difference between the answers of Khakas and Russians. Among Khakas the motives for moving to the city in connection with the search for work were indicated more often, and a third of the rural Khakas surveyed are not satisfied with their work today.

Scientists have long noted the presence of professional and industrial specialization between the Russian and Khakass population of the Republic. Conducted in the early XXI century sociological survey showed that Russians were employed mainly in heavy industries with good pay and a rich social base, while Khakas were mainly employed in small enterprises of light and food industry with low wages [Ostapenko 2003, p. 4]. As a result, most Khakas (85\%) were not satisfied with their financial situation, among Russians this figure was lower- - 64 \% [Anayban 2006, p. 5]. At the same time, the Khakas felt socio-economic inequality between themselves and the Russians, and this was manifested in different opportunities for social growth.

For 15 years the situation in the Republic has undergone significant changes through the prism of ethnicity in the sphere of employment. This is primarily due to the overall change in the structure of the region's economy. The growth of service and trade enterprises has led to the fact that today the majority of respondents, regardless of nationality, work in this sphere $19.8 \%$.

Of course, the difference between the spheres of labor activity of urban and rural Khakas is more significant. Due to the rapid growth of housing construction in the cities of the region, especially in the capital Abakan, many urban Khakas work in the construction industry today (10.9 \% of respondents). Every fourth Khakas citizen is employed in the service sector . More often than in rural areas urban Khakas are represented in all levels of government (3.7 \% vs. $2.5 \%$ ). For the sphere of work in the cities, especially in the capital Abakan, there are significant professional and qualification disparities, which often do not meet the expectations of the Khakas who arrived from the village. Thus, urban Khakas are more likely to work as workers than rural Khakas (39.2 \% vs. $30.4 \%$ ), as well as middle-level employees (27.6 \% vs. $25 \%$ ), while in rural areas it is easier for Khakas to 
move up the career ladder and take leadership positions (3.6 \% in rural areas vs. $2.5 \%$ in the city).

The impact of urbanization has a particular impact on the distribution of leisure time of the urban population. In cities, where the population has more material opportunities and a wide range of leisure activities, the free time of the population is characterized by a significant diversity. First of all, this is manifested in the availability of active non-domestic leisure. For example, today a fifth of citizens prefer to go to the cinema in their free time, $12.0 \%$ - meet with friends in cafes , $8.3 \%$ - visit theaters, museums, philharmonic, $8.8 \%$ - shopping, $5.9 \%$ - spend time in entertainment centers. Also, urban residents are more likely to engage in sports (12.2 \% vs. $5.4 \%)$.

Rural residents deprived of such opportunities prefer to spend their free time at home, doing household chores and raising children (63\%), as well as with friends, going to nature $(16.2 \%)$. Among the villagers the commitment to self-education, reading is expressed more than in the city. $16.8 \%$ of the village residents mentioned reading books, newspapers and magazines as their main leisure activity, $2.2 \%$ regularly visit the library.

Almost an equal number of urban and rural residents of Khakassia go to dances and discos in their free time, and also prefer such home entertainment as music, TV, Internet.

A distinctive feature of the everyday leisure of urban residents today is the possibility of carrying out an active out-of-home pastime. This can not but affect the degree of satisfaction of residents of urban and rural areas with their leisure activities. Today, $31 \%$ of rural respondents and $20.9 \%$ of urban respondents are not satisfied with their leisure time.

Significant differences between urban and rural Khakas are observed in the housing and household sphere. Today, the norm of comfortable living conditions is the housing of $40.1 \mathrm{~m} 2$ or more per person [Larina 2018, p. 44.] Neither in urban nor in rural areas of Khakassia the total area of residential premises, accounting for an average of 1 resident, does not correspond to this indicator. In the village it is $22 \mathrm{~m} 2$., in the city $-24.6 \mathrm{~m} 2$.

At the same time, the rural housing stock is less well-equipped with water supply (only a third of the total area of the entire housing stock), baths (18.8 \%) and hot water supply (20.2\%), water disposal (76.6 \%) is often not centralized. Therefore, the provision of urban residents with comfortable housing conditions is still far ahead of the countryside.

Despite the blurring of the boundaries between the city and the village, the spread of urban forms of culture and household the city still differs from 
the village in terms of more developed socio-economic sphere, ahead of its level of material prosperity of residents, the development of leisure space, comfortable living conditions. All this testifies to the preservation of differences in urban and rural lifestyle in the Republic of Khakassia.

\section{References and sources}

Anayban Z. V., Tyukhteneva S. P Etnokulturnaya adaptatsiya naseleniya Uzhnoy Sibiri (sovremenniy period) [Ethnocultural adaptation of the population of southern Siberia (modern period)]. - M.: Institut vostokovedeniya RAN [Institute of oriental studies RAS], 2008. - 217 p.

Zarukina E. V. Gorodskaya infrastructura i obraz zhizni gorozhan: problemy proektirovaniya [Urban infrastructure and way of life of residents: design problems] // Vestnik faculteta upravleniya SPBGEY [Bulletin of the faculty of management of St. Petersburg State Economic University]. - 2017. - № 1-1. - P. 136-140.

Larina T. N., Kibytaeva A. N. Statisticheskiy analiz faktorov uluchsheniya zhilishchnykh usloviy naseleniya gorodskoy i selskoy mestnosti Orenburgskoy oblasti [Statistical analysis of factors of improvement of housing conditions of the population of urban and rural areas of the Orenburg region] // Sotsialnaya statistika [Social statistics]. - 2018. - № 3. - P. 40-49.

Ostapenko L. V. Sotsialno-ekonomicheskiye aspekty adaptatsii russkikh I khakassov $\mathrm{k}$ usloviyam transformiruyushchegosya obshchestva (po materialam etnosotsiologicheskogo issledovaniya $\mathrm{v}$ Khakasii) [Socio-economic aspects of adaptation of Russians and Khakas to the conditions of transforming society (according to the materials of ethnosociological research in Khakassia)]. Informatsionnoanaliticheskiy bulleten № 1 [information and analytical bulletin]. - M.: Institut etnologii i antropologii RAN [Institute of Ethnology and anthropology RAS]. Tsentr po izucheniyu mezhnatsionalnykh otnosheniy [Center for the study of interethnic relations], 2003. $-26 \mathrm{p}$.

Sbornik po materialam Vsesoyuznoy perepisi naseleniya 1989: Raspredeleniye naseleniya po obshchestvennim gruppam, istochnikam sredstv sushchestvovaniya, otraslyam narodnogo khozyaistva i zanyatiyam [Collection of materials of the allUnion census 1989: distribution of the population by social groups, sources of livelihood, sectors of the national economy and occupations]. - Abakan, 1991. $54 \mathrm{p}$.

Sidorova G. P. "Preodoleniye razlichiy mezhdu gorodom i derevney”, ili sovetskaya gorodskaya povsednevnost protiv selskoy ["Overcoming the differences between the city and the countryside", or Soviet urban everyday life against rural] // Kultura i iskusstvo [Culture and art]. - 2019. - № 2. - P. 28-36. 